\title{
Youth attraction \& retention in Northeastern Ontario: A regional strategy
}

\begin{abstract}
André Robichaud, Ec.D
Youth outmigration in Northeastern Ontario is not a new phenomenon. The trend can be traced back to the middle of the $20^{\text {th }}$ century. The rates, however, have been serious cause for concern since the early 1990s. The main causes are linked to education and employment. Several indicators suggest that the region is poised to attract and retain its youth, such new mineral discoveries, an increased demand on health care services and impending exit of baby-boomers from the workforce. The author provides an overview of relevant research, an in depth statistical overview, proven attraction and retention strategies and a SWOT analysis to highlight the need for a regional youth attraction and retention strategy. The author suggests that the strategy must be all encompassing and adopted by all communities in the region.
\end{abstract}

Keywords: youth attraction \& retention, Northern Ontario, youth strategy

\section{Introduction}

Youth out-migration is a serious cause for concern for the Northeast Community Network $(\mathrm{NeCN})$ region. Youth have been leaving the $\mathrm{NeCN}$ region at an alarming rate, and for the better part of the last 20 years. According to available data, the period of 1991 to 2001 recorded the highest youth exodus rates. The rates continue to be a cause for concern to this day.

Youth out-migration is not a phenomenon unique to the NeCN region. It is a problem faced by many communities all over Canada. Youth have been leaving small town Canada for urban centres for many years. In the case of our region, the problem can be traced back to the Second World War. Young workers would come to the region to work mainly in the forestry and mining sectors, stay for a while, and then leave. Labour retention was an issue (Southcott, 2007).

A statistical overview of the region including youth out-migration rates, a review of relevant research, and a compilation of proven youth attraction and retention strategies and initiatives will be presented. The intent of the paper is twofold. The first goal is to highlight to the communities of the $\mathrm{NeCN}$ region the need for a regional youth attraction and retention strategy. Second is to build a foundation to provide recommendations and actionable strategies going forward that decision-makers may consider implementing. 


\section{Purpose}

Young people from the $\mathrm{NeCN}$ region are leaving and are not returning. The region is also seeing its overall population decrease. One can say that youth are responsible for the depopulation of the region. The $\mathrm{NeCN}$ would greatly benefit from the attraction and retention of its youth, both in terms of stabilizing its population and as an economic development tool.

The main causes for youth out-migration are a lack of employment and education opportunities. Several studies (including Arens et al., 2005-2006) have highlighted these main causes and youth in the region have confirmed similar reasons (Far North East Training Board, 2002).

In contrast, several external factors lead to the belief that the $\mathrm{NeCN}$ region is poised to retain its youth and attract others in the near future. The discovery of significant mineral deposits, a nottoo-distant rebound in the forestry sector, an increase in demand for health services because of an aging population, and an impending exodus of baby boomers from the labour force lead to the conclusion that youth will have employment opportunities.

The paper will utilize a variety of methods to evaluate the current rate of youth out-migration while at the same time identifying strengths, weaknesses, opportunities, and threats relating to the attraction and retention of youth in the region.

\section{Methodology}

The research method used in this paper was undertaken in a series of phases:

- Review of existing research, literature and studies/reports

- Drivers of youth out-migration

$\circ$ The reasons behind why youth decide to leave and what entices them to return

- Remedies to youth out-migration

- The relationship that Northern Ontario youth have with their environment

- Compilation of census of population data from 1981-2011 to understand trends of youth outmigration in the study area.

- Research on proven youth attraction \& retention strategies and determine which the communities in the study area could consider for implementation.

- SWOT Analysis for the NeCN Region

\section{Limitations}

Although several reports and studies have looked at youth out-migration from rural Canada, not many have looked at Northern Ontario and the Cochrane District, and none specifically at the $\mathrm{NeCN}$ region. The overview of relevant research focuses on Northern Ontario where possible and supplements the information with research from across Canada. 


\section{Study Area}

The study area (Figure 1) includes 12 municipalities and townships and two (2) First Nation communities in the southern portion of the Cochrane District.

Figure 1. Northeast Community Network Region

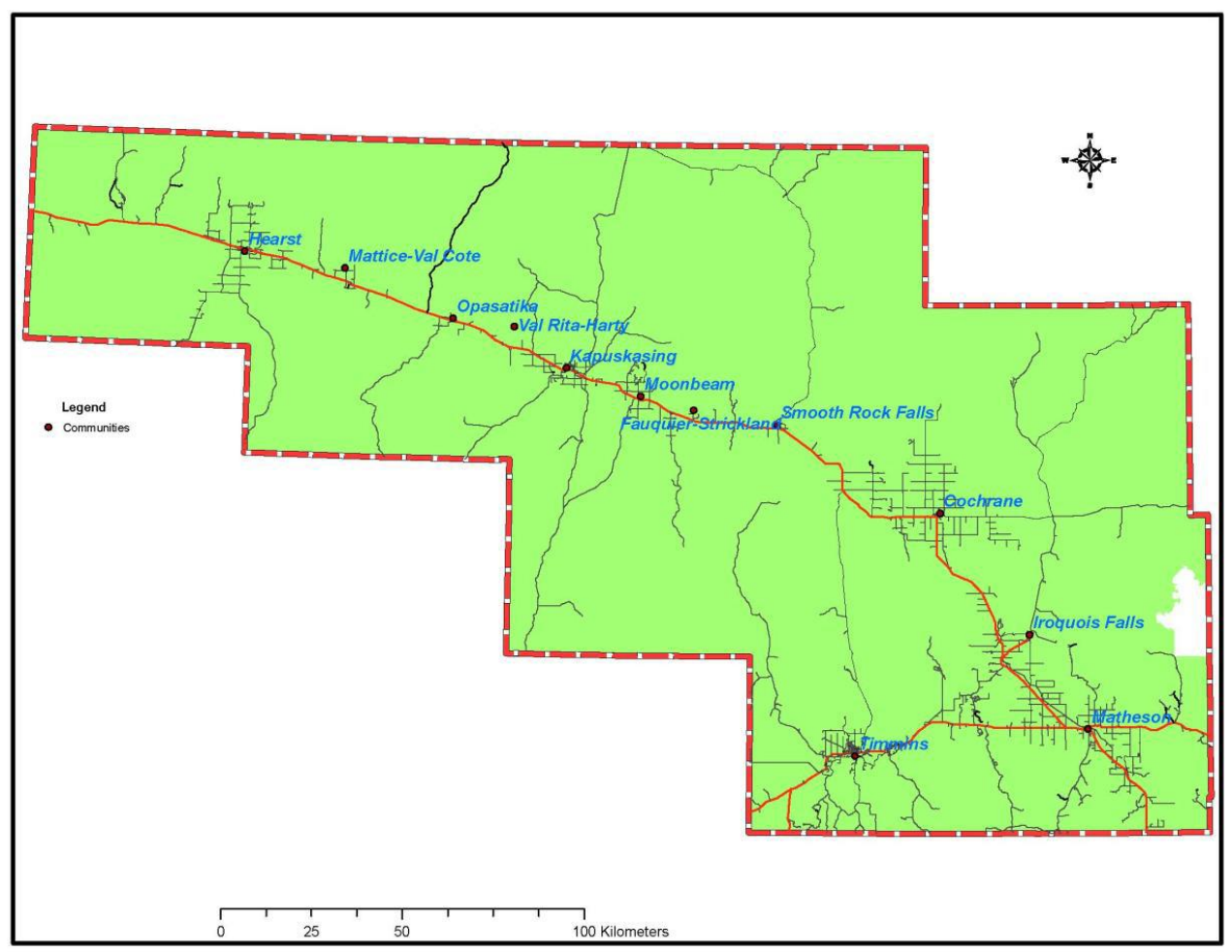

Source: Manseau, 2008

The study area will be referred to as the $\mathrm{NeCN}$ region or area. This area is not recognized as a political jurisdiction. The First Nations were not included in the analysis for this paper because population numbers were not available in all census periods.

Throughout the paper, reference will also be made with respect to youth out-migration from rural Canada. The youth out-migration trends and the reasons for youth leaving rural Canada are applicable to Northern Ontario and the $\mathrm{NeCN}$ region.

\section{Youth Out-Migration in the NeCN Region}

\section{History}

The history of settlement by non-Natives in Northern Ontario is relatively recent when compared to the rest of Ontario. Settlement is even more recent in the $\mathrm{NeCN}$ region. At the turn of the $20^{\text {th }}$ century, the passage of the Temiskaming and Northern Ontario Railway Act paved the way for the construction of a $253 \mathrm{~km}$ line from North Bay to Cochrane. Settlement started with the construction of the railway. 
Following the building of the railways, the region's development was primarily driven by the forestry and mining industry. The development of northern communities was for the most part undertaken by large corporations based outside the region as opposed to local entrepreneurs and stakeholders. This fact has meant that the socio-economic makeup of the region exhibits several unique characteristics (Fahlgren Commission, 1985; Rosehart, 1986).

The first of these characteristics relates to an over-dependence on natural exploitation. This has meant a high level of vulnerability to resource depletion, world commodity prices, changes in Canadian exchange rate, boom and bust cycles of mining and forestry industries, and changes in government policies affecting Northern Ontario (Dadgostar, Jankowski and Moazzami, 1992).

Another particular characteristic is the high degree of dependency on external stakeholders. Communities were developed by outside interests and local entrepreneurship has been limited in comparison to other areas of the province. Furthermore, the lack of entrepreneurship role models and decision-making power has created a barrier to the entrepreneurial culture in these communities.

These unique characteristics have contributed to the problem of youth out-migration and depopulation that we will review briefly later in the report.

\section{Types of communities}

Northern Ontario and the $\mathrm{NeCN}$ region can be divided into three (3) different types of communities (Table 1).

Table 1. Types of communities in the NeCN Region

\begin{tabular}{|c|c|c|}
\hline Type & Characteristics & NeCN Region \\
\hline $\begin{array}{l}\text { Small-Medium Size Cities } \\
\text { Cities over } 40,000 \text { inhabitants }\end{array}$ & $\begin{array}{l}\text { There are five (5) in Northern } \\
\text { Ontario. They are heavily } \\
\text { dependent on resource industries, } \\
\text { but are also diversified. They are } \\
\text { usually centres for health, } \\
\text { education and other important } \\
\text { services. }\end{array}$ & City of Timmins \\
\hline $\begin{array}{l}\text { Resource Dependent } \\
\text { Communities }\end{array}$ & $\begin{array}{l}\text { The vast majority of communities } \\
\text { in Northern Ontario are resource } \\
\text { dependent communities and single } \\
\text { industry towns. They are less } \\
\text { diversified and more dependent on } \\
\text { resource industries }\end{array}$ & $\begin{array}{l}\text { Town of Kapuskasing } \\
\text { Town of Hearst } \\
\text { Town of Iroquois Falls } \\
\text { Town of Cochrane } \\
\text { Town of Smooth Rock Falls } \\
\text { Township of Mattice Val-Côté } \\
\text { Township of Moonbeam } \\
\text { Township of Fauquier-Strickland }\end{array}$ \\
\hline
\end{tabular}




\begin{tabular}{|c|c|c|}
\hline & & $\begin{array}{l}\text { Township of Black River- } \\
\text { Matheson } \\
\text { Township of Val Rita-Harty } \\
\text { Township of Opasatika }\end{array}$ \\
\hline Aboriginal Communities & $\begin{array}{l}\text { Aboriginal communities in the } \\
\text { NeCN region are part of James } \\
\text { Bay Treaty \#9. }\end{array}$ & $\begin{array}{l}\text { Constance Lake First Nation } \\
\text { Wahgoshig First Nation }\end{array}$ \\
\hline
\end{tabular}

\section{Statistical Overview}

To better understand youth out-migration in the $\mathrm{NeCN}$ region it is important to provide a statistical overview.

The $\mathrm{NeCN}$ region has had a decline in its overall population dating back at least 30 years. In 1981 , the region had a total population of 86,587 and by 2011 that number had dropped to 73,520 . The trend peaked in the period $1996-2001$ where the region lost $6 \%$ of its total population. The rate of decline then decreased in 2001-2006 (-4\%) and 2006-2011 (-2\%). The $\mathrm{NeCN}$ has nonetheless lost close to $15 \%$ of its total population from 1981-2011. In comparison, Ontario's total population increased by almost 50\% during this same period.

\section{Figure 2. Change in Total Population}

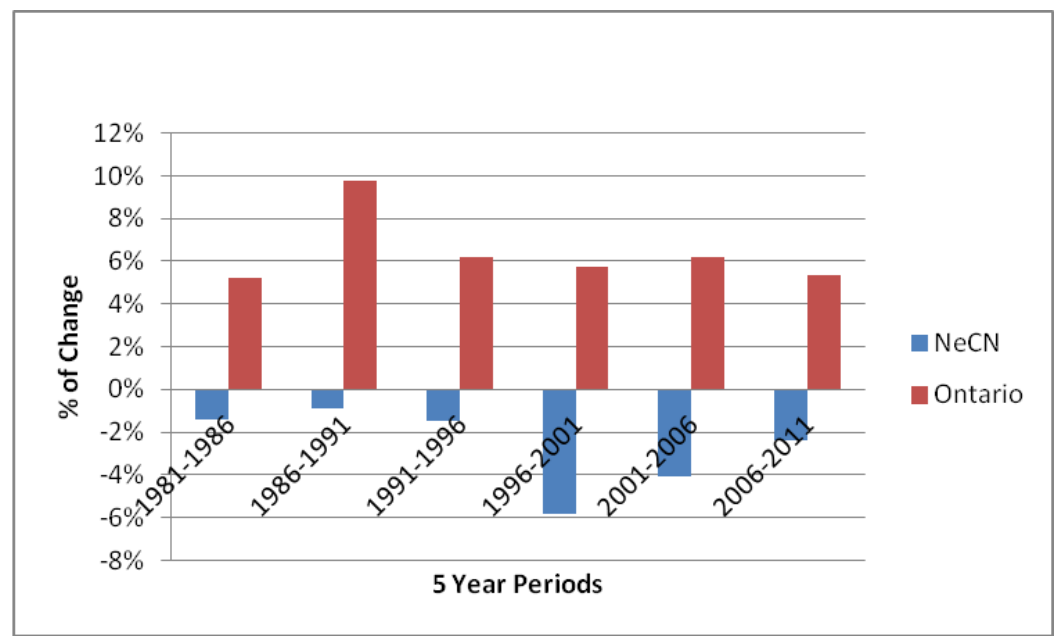

Source: Statistics Canada

The age structure of the $\mathrm{NeCN}$ region is different from the province. The largest difference occurs in the 45 to 64 years of age cohort. As a whole, the 0 to 44 years of age category is proportionatly larger in Ontario (57\%) in comparison to the $\mathrm{NeCN}$ region $(52 \%)$. The opposite is true for the 45 to $65+$ years of age category which is proportionately larger in the $\mathrm{NeCN}$ region (48\%) compared to Ontario (43\%). 
Figure 3. Age Structure in 2011

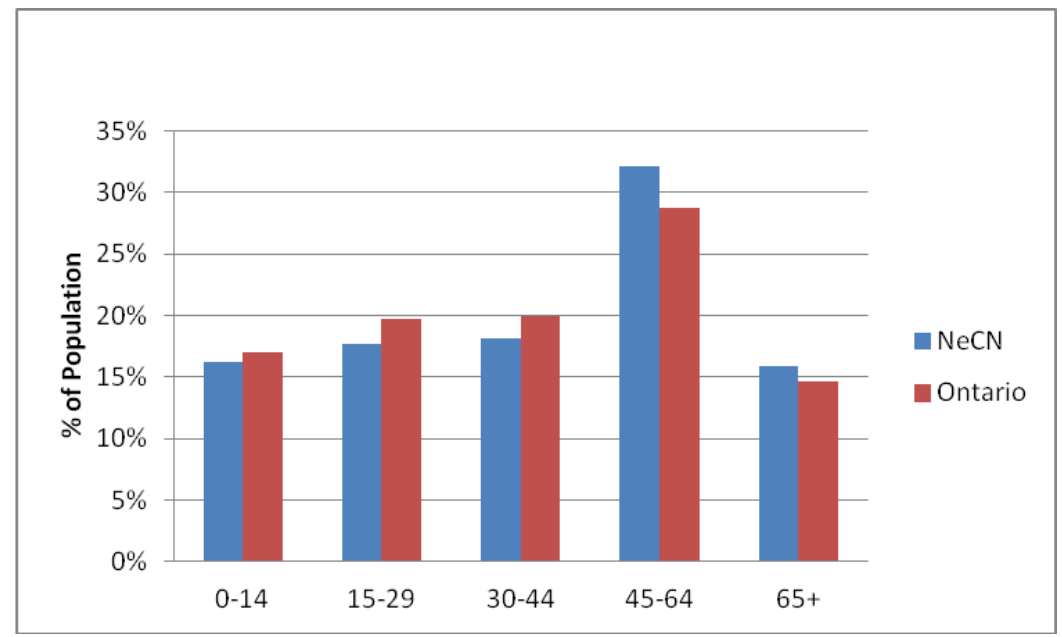

Source: Statistics Canada

The differences have not always been the same. At one point, the 0 to 44 years of age category, as a percentage of total population, was higher in the NeCN. Tables 2 and 3 depict the historical age structures of the NeCN region and the province from 1991-2011.

In 1991, the 0-44 years of age category in the $\mathrm{NeCN}$ represented $71 \%$ (Table 2) of the total population, as opposed to the province's $68 \%$ (Table 3 ). The $\mathrm{NeCN}$ region also had higher numbers in this category in $1996,67 \%$ compared to $66 \%$. The numbers were very similar in 2001, approximately 63\%. It is however evident that the numbers are now trending downwards for the $\mathrm{NeCN}$ region. The balance finally tipped in 2006 when the $0-44$ category in the $\mathrm{NeCN}$ region represented $56 \%$ of the total population versus $60 \%$ in the province. The trend continued in 2011, where proportions of $52 \%$ versus $57 \%$ were recorded.

Table 2. NeCN Region Historical Age Structure

\begin{tabular}{|c|c|c|c|c|c|}
\hline & $\mathbf{1 9 9 1}$ & $\mathbf{1 9 9 6}$ & $\mathbf{2 0 0 1}$ & $\mathbf{2 0 0 6}$ & $\mathbf{2 0 1 1}$ \\
\hline $\mathbf{0 - 1 4}$ & $23 \%$ & $20 \%$ & $20 \%$ & $17 \%$ & $16 \%$ \\
\hline $\mathbf{1 5 - 2 9}$ & $23 \%$ & $21 \%$ & $19 \%$ & $18 \%$ & $18 \%$ \\
\hline $\mathbf{3 0 - 4 4}$ & $25 \%$ & $26 \%$ & $24 \%$ & $21 \%$ & $18 \%$ \\
\hline $\mathbf{4 5 - 6 4}$ & $19 \%$ & $22 \%$ & $25 \%$ & $30 \%$ & $32 \%$ \\
\hline $\mathbf{6 5 +}$ & $10 \%$ & $9 \%$ & $13 \%$ & $14 \%$ & $16 \%$ \\
\hline
\end{tabular}

Source: Statistics Canada 
Table 3. Provincial Historical Age Structure

\begin{tabular}{|c|c|c|c|c|c|}
\hline & $\mathbf{1 9 9 1}$ & $\mathbf{1 9 9 6}$ & $\mathbf{2 0 0 1}$ & $\mathbf{2 0 0 6}$ & $\mathbf{2 0 1 1}$ \\
\hline $\mathbf{0 - 1 4}$ & $20 \%$ & $21 \%$ & $20 \%$ & $18 \%$ & $17 \%$ \\
\hline $\mathbf{1 5 - 2 9}$ & $23 \%$ & $20 \%$ & $19 \%$ & $20 \%$ & $20 \%$ \\
\hline $\mathbf{3 0 - 4 4}$ & $25 \%$ & $25 \%$ & $24 \%$ & $22 \%$ & $20 \%$ \\
\hline $\mathbf{4 5 - 6 4}$ & $20 \%$ & $21 \%$ & $24 \%$ & $26 \%$ & $29 \%$ \\
\hline $\mathbf{6 5 +}$ & $12 \%$ & $12 \%$ & $11 \%$ & $14 \%$ & $15 \%$ \\
\hline
\end{tabular}

Source: Statistics Canada

\section{Youth Out-Migration Trends}

As previously mentioned, youth out-migration is not a new phenomenon. The trend has been occurring in rural Canada since at least 1966. The country has illustrated an overall gain in its urban population at the expense of rural areas. Youth out-migration has been mainly affected by external factors.

The region has seen a high exodus of its youth population over the course of the last few decades. Following the Second World War, resource dependent communities of the $\mathrm{NeCN}$ region had trouble keeping their workers. It was difficult for small one-industry towns to keep their young workers for extended periods of time.

In the 1960s there was great cause for concern with respect to youth needing to leave the region to receive a post-secondary education. Decision-makers knew that if youth had to leave they would probably not come back, and the region would lose its future leaders. This was the reason for the creation and expansion of universities and community colleges in the immediate region, such as l'Université de Hearst and Northern College. Today there is also the presence of Collège Boréal.

It was not until the 1980s that communities started to get really concerned about youth outmigration. Simply put, youth were leaving and not returning, and the impacts extended beyond labour retention and the loss of future leaders. The region's total population started to decline during this period. The 'brain drain' of youth going to urban areas is partly responsible for the depopulation of the region.

From 1980 to 2000, various organizations produced reports that outlined the serious extent and the reasons for youth out-migration. In particular, a report by the Far Northeast Training Board (FNETB) looked at the issue in their service area. The FNETB service area is larger than the $\mathrm{NeCN}$ area, but all the communities within the $\mathrm{NeCN}$ area fall within the FNETB area. The report outlined that out-migration was still a serious issue and that it was part of the general decline of the population. 


\section{Youth Out-Migration Rate}

To understand the problem and the trends of youth out-migration in the $\mathrm{NeCN}$ region, a statistical overview will be provided on the youth out-migration rates from 1991 to 2011.

Figure 4. Youth Out-Migration Rate Formula

\section{Youth Out-Migration Rate}

(\# of youth in 15-19 age cohort in 1991 - \# of youth in the 20-24 age cohort in 1996)

(\# of youth in the 15-19 age cohort in 1991)

There is a potential problem with this formula because Statistics Canada uses a 'random rounding' technique. Nevertheless, the formula gives a very accurate snapshot of youth outmigration.

Along with the decrease in overall population, there has been a decrease in the overall population of the 15 to 29 years of age cohort. The youth out-migration rate peaked at over 19\% in the 5year period from 1996-2001, whereas the province had an increase of almost 5\% (Figure 5). The rate declined in the period of 2001-2006 and 2006-2011, 15.8\% and 10.2\% respectively. It is worth noting that there was a general decline in overall population during this same time period of $4 \%$ and $2 \%$.

Figure 5. Youth Out-Migration Rates - 15 to 29 Years of Age Cohort

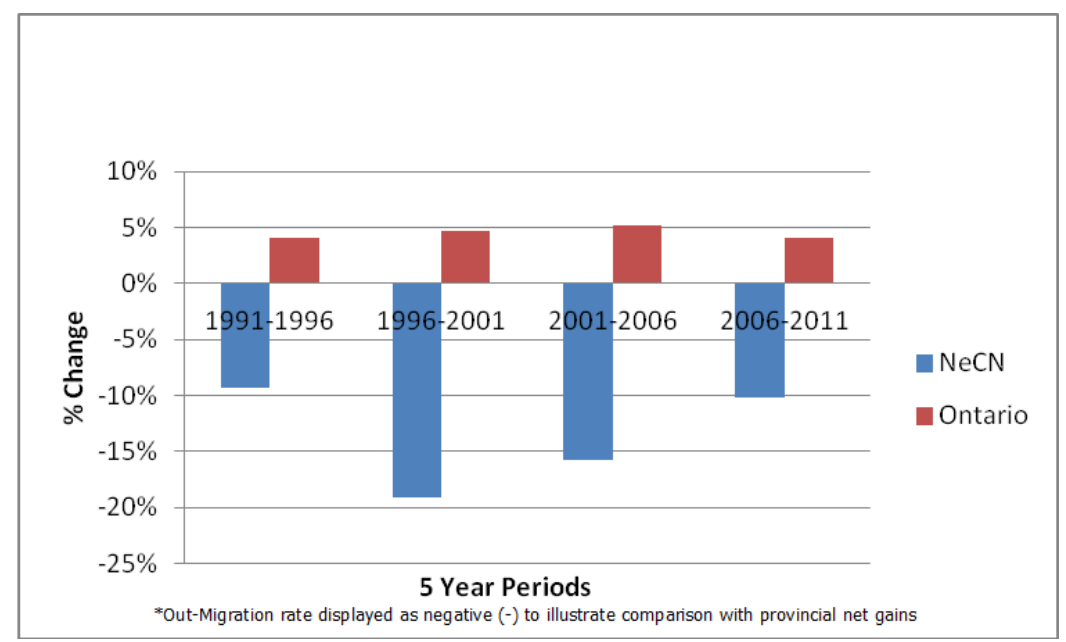

Source: Statistics Canada

Over the course of the last 30 years the male youth out-migration rate has been higher (Figure 6). From 2006 to 2011, this rate was $11 \%$ in comparison to $10 \%$ for females. There has been a general downward trend in both rates since the period of 1996-2001. 
Figure 6: Youth Out-Migration Rate by Gender in the NeCN Region

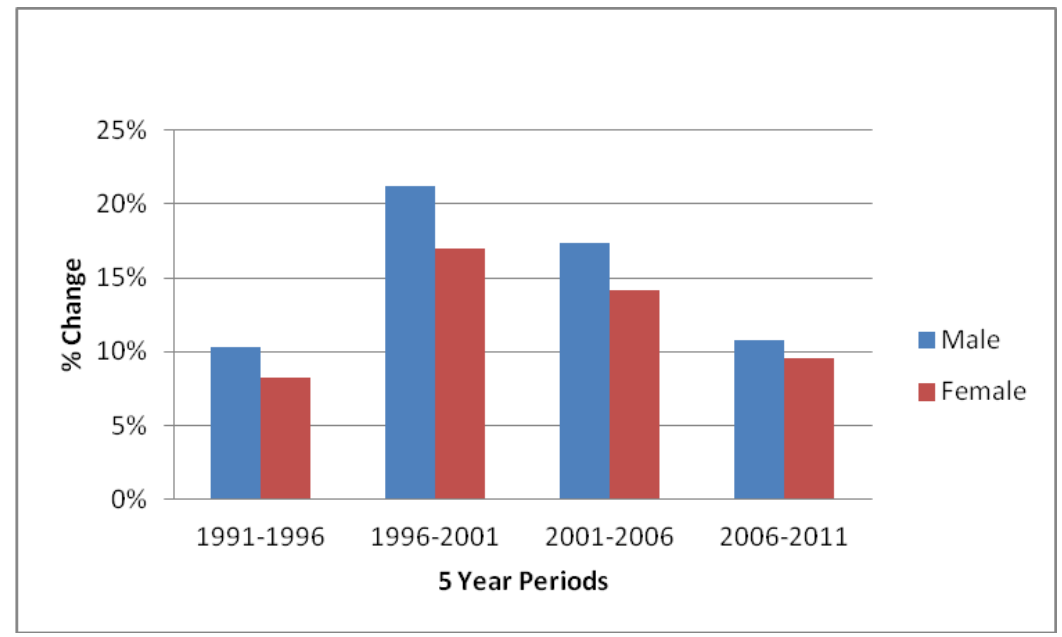

Source: Statistics Canada

The compilation of data also indicates that there are varying out-migration rates for the 15 to 19 , 20 to 24 and 25 to 29 age cohorts (Figure 7). In the period 1991-1996, the rates were 18\%, 8\% and $3 \%$ respectively. In the period from 1996-2001, the rates were $30 \%, 19 \%$ and $7 \%$. In the period of 2001-2006, the rates were $28 \%, 13 \%$ and $2 \%$. In the last period, we see continued high out-migration in the 15-19 age cohort (23\%) and moderate outmigration among 20-24 year olds (8\%), but a promising net in-migration of $5 \%$ for the 25 to 29 years of age cohort. It is worth mentioning that similar studies for youth out-migration in rural Canada illustrate the same cohort disparities (Dupuy, Mayer and Morissette, 2000)

\section{Figure 7: Youth Out-Migration Rate by Age Cohort in the NeCN Region}

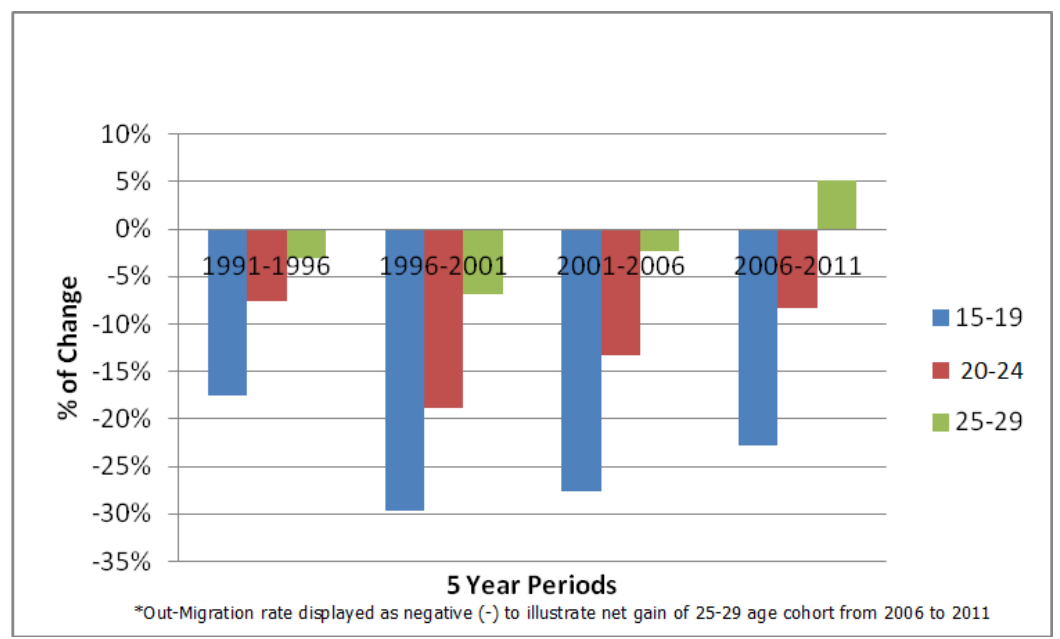

Source: Statistics Canada 


\section{The Relationship that Young People have with Northern Ontario}

Laurentian University, l'Université de Hearst and the Far Northeast Training Board (FNETB) completed a study entitled Youth and the North: A Path to Discover. The longitudinal study had two objectives. The first consisted of understanding the relationship that young people have with their environment, Northeastern Ontario. The second consisted of educating the decision-makers of this vast region about young people's representations, attitudes and behaviours. This would in turn help decision-makers take into account the information for their development projects.

The first data collected started in 2005 and consisted of two samples: a cohort in Grade 9, starting high school, and a cohort of students in Grade 12, young people on the verge of graduating high school. The intent was to follow these young people over a decade.

Below is a summary of the key findings, observations and recommendations from the seventh report (Bouchard, Bussières, Girard \& Laflamme, 2011) of the project entitled Youth and the North: A Path to Discover.

$\underline{\text { Key Findings }}$

- Nearly $33 \%$ of study participants showed a preference for Northern Ontario educational institutions.

- Nearly $33 \%$ of study participants expected to work in Northern Ontario after their studies.

- Close to $50 \%$ of students said they want to live in the region after their studies.

\section{Observations}

- The more young people like their environment and get involved in their community, the more they want to live there and pursue their studies there.

- Students choose their post-secondary institution early on, and their decision shows little fluctuation over time.

- The city of post-secondary studies is a determining factor in the future choice of residence.

- Young people's perception is solidly entrenched before the end of high school. Therefore, it is important to intervene well before high school to make the north more attractive.

\section{$\underline{\text { Recommendations }}$}

- The communities of Northeastern Ontario constitute a homogeneous region with its own identity. Measures proposed must be all-encompassing and affect the entire region, and therefore must be adopted by each community.

- Leaders must work to eliminate the Anti-North ideology (i.e. no jobs for educated people, jobs only available in trades).

- Decision-makers should seek to involve young people in the management of public affairs to get them more engaged in the community. 
- Communities should promote outdoor activities; environmental appreciation will give rise to a positive perception of Northern Ontario.

- Develop a complete educational network from daycare to post-secondary studies.

- The communities of Northeastern Ontario must develop activities that foster a feeling of belonging to a place.

- Communities must leverage all the opportunities of influencing fate that Northern Ontario can retain those who want to leave and find ways to bring them back.

- Essential to develop a positive image of the region to counter anti-north ideology;

- Link outdoor activities and love of the community; encourage more young people to enjoy the outdoors.

- Raise awareness that it is possible to work in the region with a university degree in fields other than mining and forestry.

\section{Drivers of Youth Out-Migration in Canada}

The two key causes of youth migration from rural Canada have been education and employment opportunity (Dupuy, Mayer \& Morissette, 2000). This is the main conclusion of the report Rural youth: Stayers, leavers and return migrants (funded by the Canadian Rural Partnership and the Atlantic Canada Opportunities Agency) which concentrated on the movement of youth between rural and urban Canada (Dupuy, Mayer and Morissette, 2000). Below is a summary of the key findings, supported by additional research.

\section{Education}

Education has been listed as one of the major causes of youth out-migration. The trend has been that young people leave smaller communities for larger cities to get an education, and this is where they put their education to work (Malatest, 2002). Furthermore, highly educated Canadian citizens have had a tendency to move from small towns to urban centres. This is especially evident in larger centres like Toronto and Vancouver, but also on smaller geographic scales.

Table 4. Educational Attainment - Urban Rural Divide

\begin{tabular}{|c|c|c|c|c|}
\hline Town & Population & Post-Secondary & Secondary & No secondary or post- \\
\hline Toronto & $2,503,281$ & $34 \%$ & $12 \%$ & $7 \%$ \\
\hline Ottawa & 812,129 & $37 \%$ & $11 \%$ & $4 \%$ \\
\hline Greater Sudbury & 157,857 & $26 \%$ & $13 \%$ & $9 \%$ \\
\hline Timmins & 42,997 & $22 \%$ & $14 \%$ & $12 \%$ \\
\hline Kapuskasing & 8,509 & $21 \%$ & $13 \%$ & $10 \%$ \\
\hline Cochrane & 5,487 & $19 \%$ & $14 \%$ & $14 \%$ \\
\hline
\end{tabular}

Source: Statistics Canada, 2006

This rural-urban divide also corresponds with a study produced for the Rural and Small Town Canada Analysis Bulletin (Alasia \& Rothwell, 2003). 


\section{Income}

Rural Canada has displayed lower wages in comparison to larger urban centres. Research shows that rural communities suffer from lower deteriorating average wage incomes (Singh, 2003). This represents an incentive for youth to migrate to larger cities. Canada's economic activity is shifting to large urban centres and continues to strengthen, further increasing the pull factor of youth to large cities.

\section{Employment}

Across Canada there is a pattern within rural communities that very few employment opportunities exist, along with too many low paying jobs. The job opportunities are less likely to be decision-making or influential positions, such as managers, executives and professionals. These positions are most likely to be located in urban centres, and in turn help draw youth. Smaller communities usually tend to have only a few major employers, and in many rural communities the major employer can be limited to one. Good paying jobs are usually not directed and available to youth.

\section{Why youth leave rural areas}

\section{Community Acceptance}

Community belonging and the idea of inclusion and exclusion are closely linked to youth outmigration. Research has also shown that youth must feel accepted by their community in order for them to live in it. A youth that feels like a local has a higher probability of continuing to reside in his community in comparison to one that feels excluded. A youth that does not feel a sense of belonging will most likely fall into a cycle of migrating from community to community trying to find a place where they will be accepted or where they can establish a viable lifestyle.

Youth leave their communities due to perception, environment, quality of life and whether or not their communities were "good place". The same research also goes on to suggest that youth who feel trapped within their community tend to migrate because they feel like they are living inside a box (Glendinning, Nuttall, Henry, Kloep \& Wood, 2003).

\section{Education}

The importance of education is a common theme regarding youth out-migration. Education is one of the most influential factors to youth out-migration. The absence of post-secondary studies will push youth to migrate where it is available. Households also play a significant part in youth migration. A parent's education is important as those with higher education will push their children to pursue a high level of education as well (Garasky, 2002). Parents have a large influence on a child's life decisions. 


\section{Quality of Life}

Another reason why youth leave rural communities is to achieve a higher quality of life and economic conditions. Beauchemin \& Schoumaker (2005) illustrate that diversified areas have a greater ability to lure people.

Age

Youth out-migration rates have been historically higher for the 15 to 19 years of age cohort. The 25 to 29 years of age cohort has constantly displayed lower out-migration rates. It is therefore important to use every chance possible to influence youth before high school.

\section{Employment}

Regional and local unemployment rates influence residency decisions. If the unemployment rate is high there is a higher chance of youth migrating to somewhere else with more job opportunities. Areas that have higher employment rates tend to draw people because it increases the probability of securing a job that pays a decent wage.

\section{Income}

Research shows that expected gains in initial income earnings provide a strong incentive for youth to migrate (Mills \& Hazarika, 2001). Youth who seek employment will go to areas with higher economic standards where they can generate greater income. Similar research goes on to indicate that youth in wealthier families and with higher levels of education are more likely to migrate out of their communities because they are more financially capable (Jamieson, 2000).

\section{Infrastructure}

Quality infrastructure is imperative to retaining and attracting people. The development of electricity, road and health services helps entice people to move into a community (Beauchemin, \& Schoumaker, 2005). Therefore, smaller communities should make continuous investments in infrastructure if they want to attract and retain people.

\section{Metropolitanism}

The "lure of the big city" draws youth in with its glamorous lifestyle and bigger opportunities. Leaving the small town for the big city has become what is expected of youth. It is a phenomenon that is deeply ingrained in culture.

\section{Why youth return to rural areas}

\section{Attachment}

Youth that have a strong connection with their community tend to return. The well-being of youth in small communities helps them to feel like they have a sense of belonging and a network 
of family and friends. Youth prefer to live near their parents and extended family in a community that they grew up in. This shows that attachment is very important to youth when considering returning to their community (Glendinning et al., 2003).

\section{Gender}

We have already highlighted that youth out-migration varies by age cohort. Youth out-migration is also affected by gender. Research confirms that young men are more likely not to return, whereas young women are more likely to return, to have a stronger attachment to their family or community, and to express an interest in returning (Elder, King \& Conger, 1996).

\section{Employment Availability}

Employment plays a crucial role in young people's decisions on where to reside. It is one of the main deciding factors. If communities take action to improve and promote their job

opportunities and services, this could influence youth to return and further assist in the growth of their community.

\section{Financial Reasons}

Some youth decide to leave and work outside their community because of employment and higher incomes. However, research shows that youth losing their job may influence them to return home due to a shortage of funds (Gmelch, 1980). Some studies also show that youth return to their community because it offers low housing costs (Malatest, 2002). For example, a rural youth studying in a large urban centre may find that the cost of living is greater than their home community and therefore return to enjoy the lifestyle that they have grown accustomed to.

\section{Relationships}

Relationships influence youth to return to their community. This includes relationships between couples where both have left or only one has left their community. They may return because they have future plans together involving marriage and a family. Youth that are in a relationship

are more likely to return to their community due to the pull of their significant other (Elder, King \& Conger, 1996). For example, youth who are ready to start the next chapter in their life, like choosing a place to reside, will often make this decision with their partner.

\section{Remedies to youth out-migration}

We know that they are many factors that contribute to youth out-migration in small communities. There are however some remedies to reduce the number of factors. The most important factor to minimize the number of youth leaving an area is to minimize dependence on larger areas that provide the amenities they lack. Since a region cannot influence change in the regions that youth are moving into, it then becomes the region's role to increase its pull factors and to decrease its push factors. 


\section{Economic Opportunities}

The influence of employment and education is something that is on the minds of all young people. When comparing job opportunities in smaller communities to larger urban areas, the latter excels in diversity, opportunity and specialization. The lack of educational and job opportunities in smaller communities is often a perceived one, yet perception is enough to influence the migration decision (Amanor-Boadu, Amanor-Boadu and Dyer, 2001). Therefore, it is important for communities to upgrade their employment strategies and local employment opportunity advertisements to attract and retain youth in the area. Another one is to promote local entrepreneurship.

Finding a solution to the economic problem would help solve one of the major contributors of youth out-migrating, but not entirely. Research shows that job opportunities do not guarantee that youth will stay. A study on youth behaviour found that up to $40 \%$ of rural youth would still move out of their small community if the same job were available in a larger city (Dupuy, Mayer \& Morissette, 2000)

The availability of post-secondary education and/or programs is a major impetus in the decline of rural areas. These institutions need to offer a more diverse range of programs and degrees that relate to a changing workforce. Another avenue is to offer access to skilled trades, apprenticeships, and entrepreneurship. A community can then spark youth interest and become more viable.

In the case of small towns, such as those in the $\mathrm{NeCN}$, employment relies on natural resources such as mining and forestry. Because of their association with "boom and bust" cycles, these industries often increase migration in search of employment.

Some studies have even showed that if a municipality operates with a debt, the out-migration rate is lower on average (Hamalainen \& Bockerman, 2004). Therefore a municipality that provides a higher quality and quantity of services to its residents, even if it requires a budget deficit, may reduce out-migration within the community.

\section{Quality of Life}

To improve someone's quality of life means to give them access to some of the following services or opportunities: government services, educational opportunities, neighbourliness, transportation, safety, and recreational/leisure activities. The idea is to make small communities more attractive to youth by focusing on issues relating to accessibility, locality, social setting, infrastructure, service provision, local labour markets, housing, educational opportunities, and recreational activities (Besser, 1997).

Housing is also a factor in improving quality of life and retaining youth. Smaller communities are more likely to retain and even attract youth who are looking toward starting a family or living 
on their own. If youth or young adults are already homeowners, it is less likely that they will leave because of the process of selling the home and fear of not getting a return on investment (Hamalainen \& Bockerman, 2004).

\section{Government Programs}

Government programs designed to attract and retain youth are great tools to reduce outmigration. They help increase the pull factors and decrease the push factors. The NeCN region has access to many programs, both federal and provincial, that are designed to help youth. These programs assist young people in job search, job acquisitions and entrepreneurship. They should be used as leverage to help attract and retain young people. They should also be promoted to youth at the secondary level so that they know what is available before seeking post-secondary education.

\section{Proven Youth Attraction and Retention Strategies}

Based on the research for this section, all successful youth attraction and retention strategies have the following characteristics:

- Proactive, positive and intentional when working with youth

- Use an asset-based approach when working with youth (leveraged current assets)

- Use youth-led activities with strong community buy-in

- Brand the community as pro-youth

- Involve youth that have stayed or returned

\section{Kapuskasing, Ontario}

Population: 8,200

Kapuskasing is located in Northeastern Ontario. The primary economic driver is forestry (and until recently, mining). Being a small single industry town for most of its existence, the community has gone through some "boom and bust cycles". Like most small communities in Northern Ontario, the community's youth have been leaving and not returning. In 2007, the municipality formed a youth economic development committee and launched the following initiatives:

\section{Christmas Brunch with the Mayor}

The breakfast is organized during the Christmas holiday for students and recent graduates. The community's largest employers and sector specific employers, based on student attendees, are invited to make presentations and give an outlook on employment. Youth can then network with leaders. Entrepreneurship is also a focus of the event. Young entrepreneurs are invited to participate and present their success stories. 


\section{Youth Database}

The database contains the names, field of study, and emails of current and former Kapuskasing youth. The database is utilized to stay connected to youth. Employment opportunities, community events and any other pertinent information are sent to the database.

\section{Summer Students and Interns}

The economic development office (EDO) works with local businesses to create meaningful summer employment for youth returning during summer break and internship positions for recent graduates. The EDO works with various agencies to secure funding for these positions.

\section{$\underline{\text { Rawlins County - Atwood, Kansas }}$}

Population: 2,500

The county is located in northwest Kansas and the largest community is Atwood. Rawlins County's primary industry is agriculture. The county has seen its population decline by close to $10 \%$ during the 1980 s and 1990s. When farming started to lose financial viability, youth were encouraged to leave the county to get an education and get a good paying job in the big city. This left a huge void in the 20 to 40 years of age demographic cohort. The county was losing its future leaders as well. Youth attraction and retention strategies, including the following, were put in place and things started to change in the early 2000s:

\section{Annual Youth Entrepreneurship Fair/Camp}

The annual fair is open to high school and junior high students of the region to present business ideas. They are judged on criteria and adaptability of their business plan. The fair also invites a speaker to present on youth out-migration.

\section{Leadership Program}

The camp was initially geared to 20 to 30 year olds upon their return to the county. Participants eventually found their way to city council and community boards. The model was then introduced to high schools and junior high. The county then noticed that there was a communication void between the older and younger population. This led to a forum that gathered young people, young entrepreneurs and older leaders to discuss youth out-migration and other issues important to county youth.

\section{Stay Connected to Young Alumni (Summer Interns)}

The county keeps an alumni online database with email. The goal is to stay connected to youth. Job openings in the county are sent to the alumni database. They also have an annual banquet where close to 450 alumni attend. 


\section{Impacts}

- Increase in 20 to 40 year olds

- Farm transitions

- Small business transition and start-up

- Professional recruitment of alumni

- School enrollment has stabilized

- 2010 census - old trend reversed with a population increase

\section{Barry County, Michigan}

Population: 59,000

The county is part of the Grand Rapids-Wyoming metropolitan area in western Michigan.

Youth Advisory Council (YAC)

The YAC started in 1996. The council is open to any youth between the ages of 13 to 21 who want to get involved in the county. The YAC currently has 50 members. Initiatives of the YAC are focused on grant making, community service, leadership and positive extra-curricular activities.

Impacts

- YAC members have returned to start businesses

$\underline{\text { Brookfield, Missouri }}$

Population: 4,500

Community leaders were noticing that youth were out-migrating and that there was an erosion of leadership. This is what triggered the community to band together and form a leadership task force.

Annual Brookfield Leadership Program

The leadership program targets young and old in the community.

\section{Annual Presentation of the Mailboxes to Graduates}

Each high school graduate in the town is given a mailbox when they graduate. The goal is to remind youth how important they are to the community. Each mailbox comes with a letter inside inviting the graduate to always consider Brookfield their home. Some have returned and installed these same mailboxes on their properties. 


\section{Annual Youth Entrepreneurship Summit}

All area schools receive an invitation to the summit. The annual event usually has approximately 125 participants. Businesses talk to students about their day-to-day activities, including challenges. The students then get some time to prepare a plan for the business owners. Young entrepreneurs are also invited to the summit to talk about their businesses.

\section{Middle School Students to EmPower Plant}

The EmPower Plant invites students for a half day problem-solving session. They are presented with a community situation and then have half a day to come up with solutions that they will to present to city council. Each councillor has a role to play (i.e. sympathiser, ask several questions, etc.) and youth have to present their problems and solutions.

The key factors and trends identified in the case studies above will be considered in a SWOT analysis of the case study region.

\section{SWOT Analysis for the NeCN region}

A strengths, weaknesses, opportunities, and threats (SWOT) analysis is a method of evaluation based on the achievement of the desired outcome. In the case of this paper, the desired outcome can be described as the potential to attract and retain youth in the NeCN region. The SWOT analysis will help identify the strengths, weaknesses, opportunities and threats relating to the desired outcome

The SWOT analysis was created primarily on the overview of relevant research, compilation of data, report findings and from working with youth in the region. It should be noted that some elements of the analysis could be classified as fitting within more than one category, depending on the lens used.

\section{SWOT ANALYSIS}

\section{Strengths}

- Low cost of living

- Availability of recreational activities

- Superior quality life

- Four season destination

- People-friendly

- Access to government programs (Internships/Coop, Young Entrepreneur, Summer Company, etc.)

- Affordable and available housing

- Big Fish, Small Pond

\section{Weaknesses}

- Lack of amenities (shopping, restaurants, etc.)

- Lack of educational opportunities/programs

- Lack of professional and managerial positions

- Small circle of friends

- Long and cold winters

- Low paying jobs

- Lack of pull factors 
- Northeastern Youth Entrepreneurship Initiative

- Leverage technology for post-secondary education (opportunity?)

- Availability of post-secondary
- Distance from major metropolitan centre

- Lack of economic diversification

- No presence of Anglophone university in the region

\section{SWOT ANALYSIS}

\section{Opportunities}

- High population of baby-boomers (employment opportunities, business opportunities)

- Aging population (employment in the health care sector)

- Booming mining sector \& discovery of major mineral deposits

- Leverage progressive communities and leaders currently in place

- Upswing in the forestry sector

- Leverage current funding programs (young entrepreneur, business start-ups, internships)

- Partnership between chambers of commerce, FNETB, municipalities, schools boards, large employers

- Resurgence and push for agricultural development

- Utilize technology to connect with youth (promote opportunities)

- Leverage studies and findings that highlight employment opportunities in the $\mathrm{NeCN}$ region

\section{Threats}

- Anti-North Ideology

- North / South Divide

- Getting stakeholders on board

- Employers not giving youth an opportunity

- Policies affecting Northern Ontario

- Communities competing for youth

- Big city, big money marketing campaigns

- Lack of funding to implement a strategy

- Political shift

- Pull factors from large cities

\section{Conclusion}

Youth out-migration in the $\mathrm{NeCN}$ region is a problem that communities have faced for decades. Although some smaller communities will continue to have trouble retaining and attracting youth, others are poised, with the right strategies and community buy in, to significantly reduce the outmigration rate. 
While education and employment continue to be the leading factors that lure youth to large cities, several pull factors lead us to believe that many will have the opportunity to return. The discovery of significant mineral deposits in the region and outlying areas, and an aging population along with an impending exodus of baby boomers from the labour force will create some pressures on the labour market. Youth will have an unprecedented opportunity to enter the labour force.

When observing the overall state of the $\mathrm{NeCN}$ region it is clear that while challenges do exist to attracting and retaining youth, the area holds numerous strengths and opportunities for young people. This is made clear in the preceding SWOT analysis that includes several opportunities to attract and retain young people if a region wide strategy is implemented.

The $\mathrm{NeCN}$ should develop strategies to support the goal of attracting and retaining youth in the region along with implementation targets that guide the strategies in the short, medium and long term. The communities of the $\mathrm{NeCN}$ region constitute a homogenous region. It is therefore understood that the implementation of a regional strategy must be all encompassing and must be adopted by each community.

\section{Author Biography}

André Robichaud is a lifelong resident of Kapuskasing, Ontario. André is employed by the Municipality's Economic Development Corporation and has a Certificate in Economic Development from the University of Waterloo, an Honours Bachelor of Science with a Specialization in Human Kinetics from the University of Ottawa, and has his Ec.D. designation from the Economic Developers Association of Canada. André is currently working towards completing a diploma in municipal administration.

\section{Bibliography}

Amanor-Boadu, A., Amanor-Boadu, Y., and Dyer, G. (June 21, 2001). Venture Labour Inc. Retrieved from http://www.ifama.org/conferences/Papers/Area\%20III/AmanorBoadu_Vincent.PDF.

Arens, L., Boyd, H., Miller, A., Mokedanz, J., Ricard, A., Taylor, J., Tetreault, N., and Walker, A. (2005-2006) Impacts of youth out-migration: City of Kawartha Lakes, City and County of Peterborough and Northumberland and Haliburton Counties.

Beauchemin, C. and Schoumaker, B., (2005). Migration to Cities in Burkina Faso: Does the Level of Development in Sending Areas Matter? World Development, 33(7), 1129-1152.

Besser, Terry L. (1997). Attracting New Residents to Small Towns, Iowa State University Retrieved from http://www.extension.iastate.edu/communities/news/ComCon65.html 
Bouchard, P., Bussières, L., Girard, M., and Laflamme, S. (2011). Youth and the North: A Path to Discover. Université Laurentienne, Université de Hearst and the Far North East Training Board.

Dadgostar, B., Jankowski, W.B., and Moazzami, B. (1992). The Economy of Northwestern Ontario: Structure, Performance and Future Challenges, Thunder Bay: Centre for Northern Studies, Lakehead University.

Dupuy, R., Mayer, F., and Morissette, R., (2000), Rural Youth: Stayers, Leavers and Return Migrants. Canadian Rural Partnership and Atlantic Canada Opportunities Agency. Retrieved from http://publications.gc.ca/collections/Collection/CS11-0019-152E.pdf

Elder, G.H., King, V. and Conger, R.D., (1996). Attachments to Place and Migration Prospects: A Developmental Perspective. Journal of Research on Adolescence, 6(4), pp. 397-425.

Fahlgren Commission, (1985). Final Report and Recommendations of the Royal Commission on the Northern Environment. Ontario Ministry of the Attorney General.

Far Northeast Training Board (2002). Opportunities at Home, Kapuskasing and Region - Youth Forum Action Plan.

Garasky, S., (2002). Where are they going? A comparison of urban and rural youths' locational choices after leaving the parental home. Social Science Research, 31, 409-431.

Gmelch, G., (1980). Return Migration. Annual Review of Anthropology, 9, 135-159.

Glendinning, A., Nuttall, M., Hendry, L., Kloep, M. and Wood, S., (2003). Rural Communities and well-being: a good place to grow up? The Editorial Board of The Sociological Review, 129156.

Hamalainen, K., and Bockerman, P., (2004), Regional Labor Market Dynamics, Housing and Migration, Journal of Regional Science 44(3), 543-568.

Jamieson, L., (2000). Migration, Place and Class: Youth in a rural area. The Editorial Board of The Sociological Review, 204-223.

Mills, B. and Hazarika, G., (2001). The Migration of Youth Adults from Non-Metropolitan Countries. American Journal of Agricultural Economics 83(2), 329-340.

R.A. Malatest \& Associates LTD., (2002). Rural Youth Migration: Exploring the reality behind the myths. Rural Youth Study, Phase II. Ottawa: Government of Canada. Catalogue No. A22272/2002E-IN.

Rosehart, R.G. (1986). Final Report and Recommendations of the Advisory Committee on Resource Dependent Communities in Northern Ontario. Ontario Ministry of Northern and Mines 
Southcott, C. (2007). 2006 Census Research Paper Series: \#2 - Youth Out-migration Trends in Northern Ontario: 2001 to 2006. Retrieved from http://www.awic.ca/documents/assets/uploads/files/en/2_youth_outmigration_trends_in_northern_ontario.pdf 